\section{For lettvint om EKG}

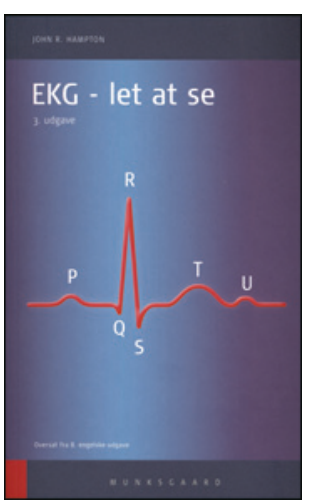

John R. Hampton

EKG - let at se

3. utg. 256 s, tab, ill. København: Munksgaard, 2016. Pris DKK 275

ISBN 978-87-628-1489-9
The ECG Made Easy ble utgitt første gang i 1973, og dette er 8. utgave. Den er solgt i en halv million eksemplarer og oversatt til et dusin språk og skal være en introduksjon til EKG for studenter (leger og sykepleiere) og annet helsepersonell.

Det er to deler - en generell introduksjon og så en del der EKG gjennomgås i lys av kliniske problemstillinger. Det er mange gode EKG-eksempler og etter hvert avsnitt en pedagogisk oppsummerende tabell.

Hvordan kan man da, som denne anmelderen, være kritisk? For det første, det pedagogiske prinsippet er mønstergjenkjennelse: «At genkende ekg-forandringer svarer i vid udstrækning til at genkende en elefant - har man set en elefant én gang, glemmer man aldrig, hvordan den ser ud.» Teksten er nærmest blottet for forklaring av hvorfor, oppsettet innbyr til pugging. Som mangeårig EKG-lærer har jeg ingen illusjoner om at slik læring holder lenge. En lege med manglende forståelse og tvilsom hukommelse kan være farlig med et viktig EKG i hendene.

Den andre innvendingen er EKG-formatet, med $25 \mathrm{~mm} / \mathrm{s}$. I Norge, Sverige og Finland brukes mest utskrifter med papirhastighet $50 \mathrm{~mm} / \mathrm{s}$, som muliggjør presise målinger. En Q-takk på $40 \mathrm{~ms}$ er som regel patologisk, mens en på $30 \mathrm{~ms}$ sannsynligvis ikke er det. Vi klarer å skille mellom de respektive $2 \mathrm{~mm}$ og 1,5 mm brede Q-takkene, men med $25 \mathrm{~mm} / \mathrm{s}$ (som er vanlig i resten av verden) blir forskjellen bare en kvart millimeter, noe som ofte etterlater tvil. Hos oss monteres som regel standardavledningene i Cabreras rekkefølge, noe som gjør det enkelt å beregne akser og se hvilke avledninger som er naboer. I boken brukes den klassiske, gammeldagse rekkefølgen. Vi opererer med bølger $(\mathrm{P}, \mathrm{T}, \mathrm{U})$ og takker $(\mathrm{Q}, \mathrm{R}, \mathrm{S})$, mens briter og dansker bruker waves/ takker om alle.

Og så er det et femtitalls altfor upresise formuleringer, viktige utelatelser og enkelte feil. Karotismassasje anbefales på riktige indikasjoner, men det er ingen advarsel om at det kan være farlig ved karstenose. Et anteroseptalt infarkt betegnes anterolateralt. Det bugner av kategoriske utsagn, som f.eks. «QRS-komplekset kan kun have tre abnormiteter - det kan være for bredt, for højt, og det kan indeholde en abnorm Q-tak». Det kan imidlertid også være for lite, og to oppsplittete (fraksjonerte) nabo-QRS regnes i dag av mange som en like sikker infarktmarkør som to patologiske Q-takker.

Men hvis man først har forstått prinsippene for EKG, kan dette være en grei repetisjonsbok før eksamen. Men andre populære og ikke mye tykkere lærebøker er langt å foretrekke.

\section{Knut Gjesdal}

Professor emeritus, Hjertemedisinsk avdeling

Oslo universitetssykehus, Ullevål

\section{Operasjonsteknikk - mye om mangt}

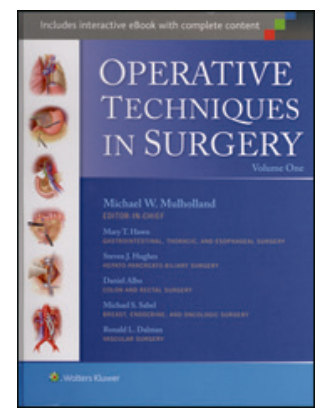

Michael W. Mulholland, Daniel Albo, Ronald L. Dalman et al, red Operative techniques in surgery

2 bd. 2304 s, tab, ill. Philadelphia, PA: Wolters Kluver Health, 2015. Pris USD 400

ISBN 978-1-4511-8631-4

Det å gi ut en lærebok på 6,1 kilo i papirformat (i to bind, mer enn 2300 sider) om kirurgisk operasjonsteknikk kan i vår digitale verden kanskje anses som et risikoprosjekt? Dette oppslagsverket omhandler nesten hele bredden av operative inngrep innen gastrokirurgi, kar- og lungekirurgi og bryst-/endokrinkirurgi og melanomkirurgi. Ortopeder, urologer, nevrokirurger og hjertekirurger vil ikke finne noe relevant. Plastikkirurger vil ha nytte av melanomseksjonen (over 100 sider) og en seksjon om brystrekonstruksjoner.

I velorganiserte kapitler og ryddige underseksjoner tar forfatterne oss gjennom et vidt spekter av operative inngrep. Både laparoskopiske tilganger og robotteknikk er godt dekket. Teksten er stort sett kortfattet, leservennlig og informativ. Relevante poenger knyttet til utredning, preoperativ vurdering og selve indikasjonene for de ulike inngrep er godt belyst. Viktige kliniske poenger er samlet i en faktaboks (pearls and pitfalls) i slutten av hver seksjon. Det viktigste og kanskje mest imponerende ved dette oppslagsverket er at de ulike stegene i de operative inngrep er forklart ved en utstrakt brukt av illustrasjoner av meget høy kvalitet. Det er tegningene som imponerer mest, enkelte fotografier har litt dårlig trykkvalitet, og noen er litt små.

Noen få trykkfeil, uheldige benevnelser på noen få illustrasjoner og noe overlapping mellom seksjoner og kapitler er vel ikke helt til å unngå i et verk som dette. Forfatterne er med svært få unntak amerikanske, og framstillingen preges selvsagt av det. Litt overraskende er det at referanselistene varierer så pass mye hva gjelder utvalg og antall. Enkelte forfattere kunne med fordel bestrebet seg på å finne mer oppdaterte og relevante artikler.

Samlet sett er dette en utrolig kilde til informasjon om og instruksjon i operativ kirurgisk teknikk. La ikke tyngden skremme deg kjøperen kan i tillegg laste ned disse to bindene som e-bok for IOS, android, $\mathrm{PC}$ og Mac - og det fungerer både på iPhone og iPad! For spesialistkandidater, overleger, utdanningsinstitusjoner og aktuelle avdelinger vil dette være en utømmelig kilde. Og selv om prisen er høy, er dette noe helt annet enn det vi finner gratis på UTube og Google. Kvalitet koster.

\section{Jon Arne Søreide}

Overlege, Avdeling for gastroenterologisk kirurgi

Stavanger universitetssjukehus 